\title{
Recent Issues in Bangladesh-India Relations: A Bangladeshi Perspective
}

Dr. Md. Abul Kashem ${ }^{\dagger}$

\begin{abstract}
What are the recent issues in Bangladesh-India relations that determine the nature of the bilateral relations? This article is an attempt to investigate this question. It argues that there are a number of pertinent issues that determine the nature and state of Bangladesh-India relations. In this context, security, trade, visa, cricket, power, connectivity remain as vital issues. The article recommends that in this age of shared peace, security and prosperity, Bangladesh-India needs to explore and utilise the untapped potentials.

Key words: Bangladesh, India, Cricket, Security, Connectivity, Trade, Water
\end{abstract}

\footnotetext{
${ }^{\dagger}$ Professor and Chairman, Department of International Relations, Rajshahi University, Bangladesh, Email: mak_ruir@ru.ac.bd

(C) 2016 Kashem. This is an Open Access article distributed under the terms of the Creative Commons Attribution License (http://creativecommons.org/licenses/by/2.0), which permits unrestricted use, distribution, and reproduction in any medium, provided the original work is properly cited.
} 


\section{Introduction}

If one looks at the history, before 1947, India, Pakistan and Bangladesh was a single region popularly known as Indian subcontinent. Then through partition in 1947, India was divided into India and Pakistan. Until 1947, today's Bangladesh was known as East Pakistan. Bangladesh heralded its traumatic birth in 1971. In fact, in the Liberation War of Bangladesh, the contribution of India in all dimensions politically, diplomatically, militarily, and economically is widely recognised in Bangladesh. For instance, reportedly, besides providing support and refuge to the people of East Pakistan, former Prime Minister of India, honourable Mrs. Indira Gandhi, travelled across the world to mobilise support for the Bangladesh Liberation War. And Bangladesh though delayed, during its 40th independence anniversary in 2011 conferred the Bangladesh Swadhinata Sammanona on Mrs. Indira Gandhi posthumously for her 'outstanding contribution' to the country's independence. Thus, the Bangladesh-India relations began positively.

Though started positively, Bangladesh-India relations have experienced vicissitudes over time (Rashid, 2010). Throughout decades, certain issues have determined BangladeshIndia relations including border dispute, maritime dispute, trade, water, and transit issue. This short article focuses on the recent issues in Bangladesh-India relations. It is found that among other issues, commerce, connectivity, water has been major issues in determining Bangladesh-India relations. Among them, land boundary dispute and maritime dispute has been resolved peacefully. But there are a number of recent issues, which is determining Bangladesh-India relations to many extents. It argues that security, trade, visa, cricket, power, connectivity remain as vital issues in Bangladesh-India relations. The following section concentrates on the recent issues in India-Bangladesh relations.

\section{Geo-strategic and Security Issues}

Geo-strategic and security issues remain important dimension in Bangladesh-India relations (Sobhan, 2011). It can be argued that during honourable Mr. Narendra Modi's regime, New Delhi tried to reach New DelhiDhaka ties to a new height from economic, political or geo-strategic dimensions. Regarding geo-strategic calculus, it can be argued that New Delhi is attaching great significance to Dhaka. As the editorial of The Hindu writes, 'Mr. Modi's team made Ms. Banerjee understand the geostrategic significance of Bangladesh ... which made two quick visits to Dhaka, after having refused to accompany the then Prime Minister on his visit in 2011' (The Hindu, June 8, 2015). Hence, one of the agreements signed during Mr. Modi's visit in Dhaka, 'allowing Indian cargo vessels to use the Chittagong and Mongla ports has huge strategic implications' as noted by the Times of India (Times of India, June 7, 2015). The daily also termed that Indian gain of access to use the port as a 'big achievement' in economic terms.

In fact, the most recent issue in BangladeshIndia relations is security issue. The visit of Indian foreign secretary in May 2016 was to discuss about security issues in Bangladesh and its implications in its neighbours including India. India intends to ensure stable and peaceful situation in Bangladesh as it will also be the paramount interests of India.

As a stable government is in power in Dhaka, then one can certainly expect a sound and healthy Bangladesh-India relation. For this issue, the centre-left political elements are better as against the centre-right someone might argue.

\section{Trade Issue}

Trade has been an important dimension in Indo-Bangla relations since the independence of Bangladesh. It is pertinent to note that since 1971 until 2004, India was the largest trading partner of Bangladesh. However, China's trade with Bangladesh has manifold in recent years

C 2016 Kashem. This is an Open Access article distributed under the terms of the Creative Commons Attribution License (http://creativecommons.org/licenses/by/2.0), which permits unrestricted use, distribution, and reproduction in any medium, provided the original work is properly cited. 
and even surpassing India from 2004 onward. Notably, China is providing duty free access to more than 4,700 Bangladeshi products. Hence, India also needs to open its market for Bangladeshi products and provide duty free access.

In Bangladesh-India bilateral trade, the major problem lies in the huge trade imbalance as shown in Table 1 . This huge trade imbalance

\section{Table 1: Bangladesh-India Bilateral Trade (Value in million US \$)}

\begin{tabular}{llll} 
Year & Export & Import & Trade Ratio \\
\hline $2008-09$ & 274.26 & 2863.19 & $1: 10$ \\
\hline $2009-10$ & 304.62 & 3202.1 & $1: 11$ \\
\hline $2010-11$ & 512.5 & 4560 & $1: 9$ \\
\hline $2011-12$ & 490.42 & 4758.89 & $1: 10$ \\
\hline $2012-13$ & 563.96 & 4776.9 & $1: 8.47$ \\
\hline $2013-14$ & 456.633 & 6035.5 & $1: 13.22$
\end{tabular}

Source: Import Payment, Bangladesh Bank and Export Statistics, Export Promotion Bureau

\section{Issue of Connectivity}

Connectivity issue is a priority area in recent Bangladesh-India relations. In fact, during the visit of Mr. Narendra Modi in 2015, a number of agreements and memorandum of understandings including agreement on Coastal Shipping have been signed on connectivity issue. Inland water transport mode will be cost effective and environment friendly. According to the study of RITES in 2014 titled "Integrated National Waterways Transportation Grid", the cost of movement of freight (Rupees. per Tonne $\mathrm{Km}$.) after taxes is ₹2.58 for highways, ₹1.41 for railways and ₹1.06 for Inland Water Transport (IWT). India High Commission in Dhaka notes that three vessels from Bangladesh that is, MV Harbour-1 with effect from (w.e.f. 17.02.2016 to 16.02.2017), MV KSL Gladiator (w.e.f. 30.03.2016 to 29.03.2017) and MV KSL Pride (w.e.f. 30.03.2016 to 29.03.2017) have been permitted to operate under the India-Bangladesh agreement on coastal shipping under the Standard Operating Procedures (SOPs), which are in place. MV Harbour-1 visited Krishnapatnam Port, Andhra Pradesh in March-2016. It is also claimed that the promotion of coastal shipping will be cost effective and hence, will contribute to increase India-Bangladesh bilateral trade (High Commission of India, Dhaka, May 5, 2016). needs to be addressed through exploring new avenues of bilateral trade. In that case, tariff and non-tariff barriers imposed by India for the Bangladeshi businesspersons need to be removed. In fact, during his visit to Bangladesh in June 2015, Mr. Narendia Modi emphasised on increasing bilateral trade that needs to be implemented through effective actions. Political will is important in this context.

\section{Water Issue}

Since the establishment of Bangladesh-India relations, water has been a contending issue. Water dispute deteriorated Bangladesh-India relations in many respects. Even Bangladesh went to the United Nations in the 1980s to resolve her water issue with India. In fact, being an upper riparian country, India controls and diverts the flow of water through creating dams, which negatively affects agriculture and fisheries in Bangladesh. The signing of Ganges Water Treaty in 1996 was a major development to resolve Bangladesh-India water sharing dispute. Recently the Teesta water sharing issue has occupied an important dimension in determining Bangladesh-India relations. It is argued that due to internal political calculations, Teesta has remained an unresolved issue. Thus, Mamata Banerjee, the current Chief Minister of West Bengal needs to stop her vote politics over Teesta. For longterm interests and consolidated BangladeshIndia relations, Teesta issue needs to be resolved at the earliest.

\section{Power and Internet}

Issue of power and internet is a new avenue of cooperation between India and Bangladesh. Given growing demand of power both in India and in Bangladesh, promoting cooperation on 
this issue becomes crucial. In fact, this cooperation has already started. For instance, on 23 March 2016, Prime Ministers of India and Bangladesh jointly inaugurated, through video conferencing supply of 100 megawatts of power from Tripura, India to Comilla, Bangladesh and 10 GBPS broadband internet from Cox's Bazar, Bangladesh to Agartala, India. This cooperation has been defined as a 'historic' one in case of India-Bangladesh relations. As Indian Prime Minister Mr. Narendia Modi rightly points out that '[i]n my opinion this is an historic occasion... In an era of inter-dependent world, the two nations [IndiaBangladesh] have further strengthened their ties' (Indian Express, March 24, 2016). Bangladesh Prime Minister Sheikh Hasina said, ' $[t]$ he relation between the countries has further consolidated through the supply of power and Internet bandwidth' (Indian Express, March 24, 2016). There is an ample scope to broaden Indo-Bangla relations in different dimensions including power and internet cooperation.

\section{Cricket in Bangladesh-India Relations}

Sometimes emotions play an important role in terms of Bangladesh-India relations. During the World T-20 cup, when against the appeal of India, two Bangladeshi cricket players including Taskin Ahmed was banned to play in the tournament, each and every Bangladeshi via the social media (particularly the facebook) users became anti-India as their status update clearly testify this. At the same time, when another Bangladeshi cricketer like Mustafuzur Rahman plays in Indian Premier League (IPL), Bangladeshi people became interested about Indian IPL cricket. In addition, in a recently held seminar on Bangladesh-India relations in Dhaka, the speaker Prof. Biddut Chakrabarty from Delhi University brought the name of Mustafizur Rahman in India-Bangladesh relations. Prof. Chakrabarty mentioned that cricket is changing the landscape in IndiaBangladesh relations. In and every newspaper in India, coverage of Mustafizur has become common which is playing an important role to change the psyche of Indians regarding
Bangladesh and its people. Besides, he also mentioned that every newspaper prioritises Bangladeshi issues nowadays, which were rare 20 years earlier. For instance, the daily Ananda Bazar devotes one page for Bangladesh. Even the number of fans of Mustafizur Rahman is more than that of Virat Kohli the Indian cricketer as argued by Prof. Chakrabarty. Thus, cricket has become an important catalyst to change the discourse of India-Bangladesh relations.

\section{Visa Issue}

Visa issue works as a major impediment in elevating Bangladesh-India relations at peopleto-people contact level. In fact, Bangladeshis need to face many hassles while applying for an Indian visa, hindering smooth and flexible people-to-people contacts. This visa issue needs to be eased and flexible. Introducing Evisa can be imperative to promote Indo-Bangla relations. In this context, Naveen Agarwal and Md. Shariful Islam write that 'e-visa would ensure smooth, safe and hassle-free people to people exchange. And, needless to mention, this e-visa will transform Indo-Bangla ties to a larger extent, which might affect other areas' (Agarwal and Islam, 2015).

\section{Academia and Media}

Academia and media can work as a catalyst either to boost or deteriorate Bangladesh-India relations. There is a lack of engagement in these dimensions between these two countries. Notably, there is a lack of scholarship in IndiaBangladesh relations. This aspect is quite marginal among academic communities in Bangladesh and in India. As theory translates into practice, this neglected area of study needs to be accelerated and there must be a number of joint research projects between Bangladeshi and Indian scholars. In addition to serious academic studies, other programmes can also be handy to boost India-Bangladesh relations. For instance, India-Bangladesh Chamber of Commerce and Industry (IBCCI) and the High Commission of India in Bangladesh on 29th March, 2014 at Ruposhi Bangla Hotel, Dhaka organised a seminar entitled 'Foreign Investment in Bangladesh: Opportunities and 
Prospects' with special session on Power Sector. Such practices need to be increased to exploit the full potentials in India-Bangladesh relations.

The role of academic community is critically important to elevate Bangladesh-India relations or to resolve the bilateral disputes. In an increasingly water conflicts, hydro-diplomacy has emerged as a major tool to address water issues. Hence, in the introduction, development and expansion of hydro-diplomacy courses and curricula at University level, the role of the academics is crucial one. And effective hydrodiplomacy can be imperative to resolve IndiaBangladesh water sharing disputes. In addition, it is observed that in both the borders some academics for the sake of narrowly defined 'national interests' helps to sustain such disputes through their 'hawkish' stance in their writings. In fact, such types of academic work sometimes influence the policies of the decision makers. Such academic practice is a major hindrance to the consolidated Bangladesh-India ties. Hence, the role of the academics needs to be redefined focusing on constructive engagements.

Another aspect is about the role of the media. Indian and Bangladeshi media needs to play constructive role in resolving such longstanding disputes. In fact, through creating public opinion, confidence building through disseminating research, education and findings, media can play crucial role to resolve many disputes. Notably, in case of Land Boundary Agreement (LBA), media in both the countries played considerably constructive roles. For instance, the editorial of The Hindu in May 5 entitled 'Local politics in foreign policy' as well as in The Indian Express in May 6 entitled 'Delhi's turn India must keep its word to Bangladesh and push through the Land Boundary Agreement' played vital role to convince the politically divided factions in India over LBA. Similarly, the media in Bangladesh too played constructive role in case of LBA.

In the context of academic practice, it is argued that Bangladesh, being surrounded in three sides by India and having a strong trade and economic ties with India, having a sound knowledge over each other is imperative to elevate their bilateral relations. Better theory in fact, translates into better policies. However, in case of India-Bangladesh relations, there is a dearth of academic practice. Very few scholars, in fact concentrate on India-Bangladesh scholarship. In addition, 'South Asia' as an academic area of inquiry is a neglected area in the academic world, which also merits serious food for thought. Needless to say, this lack of academic practice works as a major challenge to uplift India-Bangladesh relations. Thus, promoting scholarship on India-Bangladesh relations becomes crucial. In this context, establishing 'Contemporary India Study Centre (CISC)' in Bangladesh and 'Contemporary Bangladesh Study Centre' (CBSC) in India will be imperative.

\section{Concluding Remarks}

One can argue that issues in Bangladesh-India relations will not be completed until or unless one looks at the recent developments in ChinaBangladesh ties and its impact on India. It is observed that though during the liberation war of Bangladesh, China tilted towards Pakistan and took time to recognise the independent Bangladesh, but over time China-Bangladesh relations deepened and enjoyed warm relations. Currently, Bangladesh-China is enjoying a robust and comprehensive partnership. Considering the geo-political realities of South Asian and external powers engagements in the region certainly creates a concern to India. The growing Chinese presence is clearly evident. In many cases, China is surpassing India in case of its relations with India's small neighbours. For instance, since 1971 until 2004, India was the largest trading partner of Bangladesh, which has been replaced by China. In addition, a growing SinoBangladesh security cooperation is also noticeable which is often viewed as a major concern to Delhi. Such growing Chinese presence in Bangladesh is viewed as China's 'string of pearl' policy to counter India. China's growing economic and political engagement over India's neighbouring countries is termed 
by Varun Sanhi as 'Chinese design and India's default' which has made India's position very weak regionally which ultimately hampers India's interests and ambitions (Sanhi, 2007: 25). One can argue, consolidated ChinaBangladesh ties made compulsion to India to deepen her relations with Bangladesh as well. Thus, the paper argues such growing ChinaBangladesh ties need to be looked upon as opportunity for an effective Indian policy towards Bangladesh. In fact, the location of Bangladesh is geo-strategically important and can be a hub between South Asia and Southeast Asia, which needs to be utilised for the shared regional prosperity by both New Delhi and Beijing. The bottom-line is that the issues discussed above, need to be properly explored and harnessed for the greater interests of the people of both India and Bangladesh.

\section{References}

Agarwal, Naveen and Islam, Md. Shariful (2015). Indo-Bangla Relations: Searching for New Frontiers, The Daily Sun, 3 October.

High Commission of India, Dhaka (May 5, 2016). Promoting Coastal Shipping between India and Bangladesh, Press Release, http://www.hcidhaka.gov.in/pages. php?id=195 61.

Rashid, Harun ur (2010). Bangladesh-India Relations: Living with a Big Neighbour, Dhaka: AH Development Publishing House.

Sahni, V. (2007). India's Foreign Policy: Key Drivers. South African Journal of International Affairs, 14, 21-35, DOI: 10.1080/10220460709545493.

Sobhan, Farooq (2011). Bangladesh-India Relations: Security Perspectives, Dhaka: Academic Press and Publishers Limited.
The Hindu (June 8, 2015). Editorial: Modi's Day in Dhaka. The Hindu, June 8, 2015. Retrieved on May 8, 2016 from:

http://www.thehindu.com/opinion/editorial/m odis-day-in-dhaka/article7291974.ece

The Indian Express (March 24, 2016). Take 100 MWs of power, give $10 \mathrm{Gbps}$ Internet Speed: India-Bangladesh Deal. The Indian Express, Retrieved on May 21, 2016 from:

http://indianexpress.com/article/india/indianews-india/take-100-mws-of-power-give-10gbps-internet-speed-indo-bangla-newdeal/\#sthash.uPSw6Y1x.dpuf

Times of India (June 7, 2015). Now, India Gets to Tug at China's 'String of Pearls'. Times of India, Retrieved on May11, 2016 from: http://timesofindia.indiatimes.com/india/NowIndia-gets-to-tug-at-Chinas-string-ofpearls/articleshow/47570510.cms

\section{About the Author}

Dr. Md. Abul Kashem obtained his Ph.D. in History from Jadavpur University, West Bengal, India. He has been working as a full-time faculty since 1986 (from 2000 as a full-time Professor) in the University of Rajshahi, Bangladesh. He was the Chair of the Department of History previously. Currently, Dr. Kashem is the Professor and Chair of the Department of International Relations. His research interests cover contemporary Political History, History of International Relations, International Relations of South Asia, Foreign Policy, etc.

\section{Acknowledgements}

I am thankful to the editor(s) of the Journal Space and Culture, India and to the anonymous reviewers for their valuable comments and suggestions. 